UDC 621.391

O.O. Avilov, I.I. Borovskyi, M.A. Zhukov, K.O. Ivanko, Ph.D, A.A. Popov, Ph.D, V.A. Fesechko, Ph.D. Biomedical Electronics and Signal Analysis Group, National Technical University of Ukraine «Kyiv Polytechnic Institute», off. 423, Politekhnichna Str., 16, Kyiv, 03056, Ukraine.

\title{
Permutation entropy of fetal heart rate with extraction of maternal heartbeats
}

Development and application of maternal and fetal physiological states identification techniques based on the noninvasive electrical heart activity monitoring is of great clinical importance during pregnancy. In this paper, new possibilities of applying one of nonlinear measures of time series behavior analysis to the fetal heart rates are explored, and permutation entropy (PE) characteristics of fetal rhythmograms are used to get new insight on the fetal heart rhythm parameters. The new technique of fetal electrocardiogram (fECG) extraction is used, based on filtration in wavelet domain and reconstruction of fECG using detalization coefficients. Permutation entropy analysis is applied to obtain PE values and trends for the case of raw fetal rhythmograms and those obtained with excluded maternal heart beats. The assumption about the need to extract maternal heartbeats from initial rhythmogram is proven by the difference in PE values for two cases. Ref. 11, figs. 11.

Keywords: permutation entropy, heart rate, $H R V, E C G, f E C G$, fetal ECG, maternal ECG, Rpeaks detection.

\section{Introduction}

Development and application of maternal and fetal physiological states identification techniques based on the noninvasive electrical heart activity is directed to prediction and control of heart diseases on the early stage of pregnancy [1] and favored mainly from the high resolution recording and signal analysis technologies. Of main interest are the possibilities to detect fetal distress, hypoxia, breathing movements, fetal heart functioning and other, to identify possible deviations and/or diseases in fetus development. Many researchers have been developing new techniques for fetus and mother state evaluation using various noninvasive modalities such as electrocardiography, Doppler ultrasound, MRI etc. The main focus is on the fetal heart rate analysis [4-6] for assessment of fetal development, prenatal diagnosis, and autonomic nervous system functioning during pregnancy.
The goal of this paper is to study the permutation entropy (PE) characteristics of rhythmograms to get new insight on the fetal heart rhythm parameters. We have applied PE to the fetal heart rhythm calculated for two cases, dealing with the problem of potential presence of maternal R-peaks in the processed fetal electrocardiogram (fECG) and shown that there is significant difference for these cases.

\section{Fetal heart beats detection}

Despite of high level of medicine nowadays, estimation of prenatal normal and pathological states is far from its final solution because of the lack of our knowledge about fetal physiology and pathophysiology. Automated analysis of measured data can provide researchers and clinicians with objective information about fetus state and functioning. The most beneficial approach is the analysis of fetus heart beats, registered and detected by cardiotocography or fetal electrocardiography [9]. There are several characteristics of fetal heart beats [9] based on the interbeat intervals:

- arrhythmicity levels of different types (oscillatory, linear, arrythmic);

- basal frequency;

- variability magnitude;

- variability frequency;

- accelerations and decelerations of different types (early, late, variable, prolonged).

Estimation of electrical activity of fetus heart is an inherent diagnostic procedure during pregnancy. The most informative is the fetal ECG (fECG) signal which should be registered with high signal-to noise ratio. After registration of ECG signal containing mother and fetus activity (Fig.1), separation of fECG from maternal ECG should be done, based on the differences in their magnitude spectral, shape and other characteristics. Among the existing techniques to solve this task those based on wavelet transform and blind sourceseparation are the most effective $[2,7,10]$. 


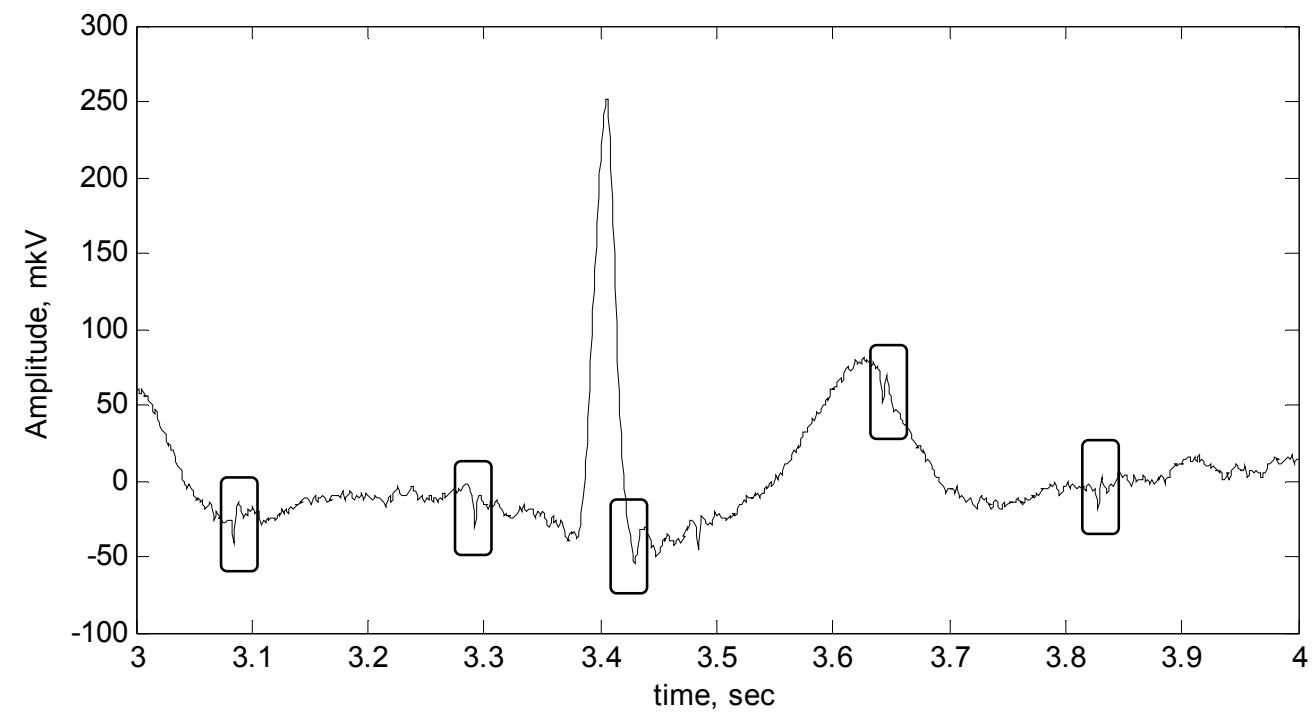

Fig. 1. Example of maternal ECG QRS complex with peaks from fetal heart beats (boxes)

In this paper the new technique of fECG extraction from the mixture of maternal and fetal ECGs is used. This approach is based on discrete wavelet analysis (DWT). First, appropriate mother wavelet function should be selected, which resembles the shape of fetal QRS complexes and thus allows its detection in abdomen ECG with higher accuracy. After that abdomen ECG $S(t)$ is decomposed into detalization $D_{j}(t)$ and approximation $A_{m}(t)$ parts using standard DWT technique:

$$
S(t)=A_{m}(t)+\sum_{j=1}^{m} D_{j}(t)
$$

where $\mathrm{j}$ is the decomposition level.

Approximation coefficients contain low-varying signal components, while detalization coefficient resemble high-frequency fluctuations. Noise components are concentrated in the detalization coefficients thus they should be processed in orderto remove high-frequency noise. To do this, the threshold should be chosen first, and then hard thresholding procedure is applied. After thresholding ECG is reconstructed using only detalization part of the appropriate decomposition level. This level is empirically optimized to obtain only fECG part in reconstructed signal.

Then simple geometric approach can be employed to get precise positions of fetal R-peaks: one needs to find starting and ending point of fetal QRS complex and then the time position of R-peak occurrence is assigned to time instant in the middle point. This approach can be used to extract fECG only owing to the fact that the reconstruction and filtration introduces the same delay into the processed ECG, thus the RR-peaks intervals will remain the same.
Another possibility to obtain rhythmogram is to process the recovered ECG signal after filtration. Having the presumably only-fetal QRS-complexes singled-out, the next task is to choose and elaborate the R-peaks detection algorithm. One of the most robust and widely used algorithms is the Pan-Tompkins algorithm [8]. It starts from bandpass filtering. After applying the filter the signal is differentiated to provide the QRS-complex slope information. Then to obtain waveform feature information in addition to the slope of the R-wave the moving-window integration is used. And finally in order to get the R-peaks thresholding is applied. In the present paper the algorithm is implemented as is up to the thresholding part which should be remodeled for the case of amplitude-varied $\mathrm{R}$ peaks.

\section{Permutation entropy of rhythmogram}

The PE is a measure of disorder of information contained in comparing the consecutive values of the signal [3]. The PE shows the extent to which analyzed signal is random (chaotic). It is based on approaches of symbolic dynamics and uses the relative frequencies of various patterns encountered in signal samples. Such approach benefits from the fact that PE does not depend on signal values and uses only symbol sequence.

Permutation entropy of integer order $\mathrm{m}(m \geq 2)$ of asignal $x[n], n=0 \ldots N-1$ is given in [3] by:

$$
\operatorname{PermEn}_{x}(m, I)=-\sum_{j=1}^{m !} p\left(\pi_{j}\right) \log p\left(\pi_{j}\right),
$$

where $m-$ is the order of PE. It affects the number of patterns that can be found in the signal. Order $m$ equals to the number of samples to be taken from 
the signal to construct one pattern. Selecting large order leads to detection of additional patterns in the signal, i.e. more variations of successive samples' combinations; I - lag. It is responsible for the time interval between signal samples with which they are elected in patterns (Fig. 2); $p\left(\pi_{j}\right)$ - relative frequency of permutation $\pi_{j}$ for signal $x[n]$. It is defined as:

$$
p\left(\pi_{j}\right)=\frac{q(j)}{N-(m-1) l},
$$

where $q(j)$ is the number of occurrence of permutation $\pi_{j}$.

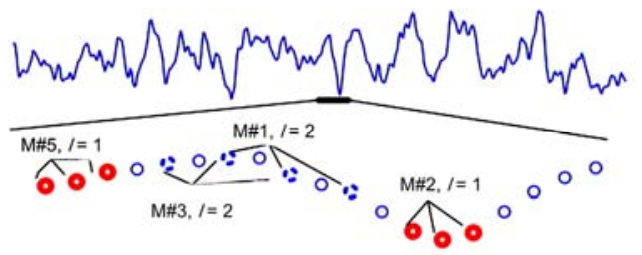

Fig. 2. Patterns in signal for different time lags [11]

A more detailed mathematical foundations of the method's calculation are given in the papers [ 1 , 3].

Embedded pattern thus consists of $m$ different numbers (Fig. 3), which represent one of $m$ ! possible permutations. Therefore each pattern can be considered as one of $m$ ! permutation (Fig. 4), and is denoted $\pi_{j}, j=1 \ldots m$ !

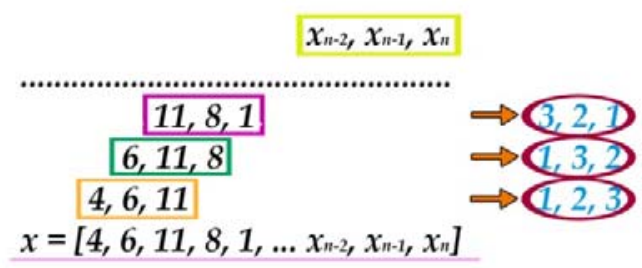

Fig. 3. How patterns are formed for PE with order $\mathrm{m}=3$

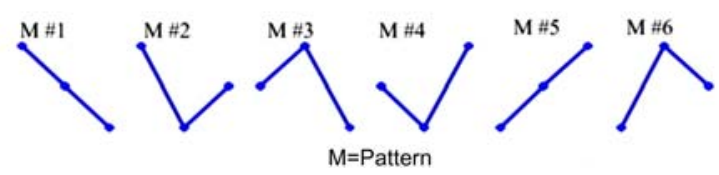

Fig. 4. All possible patterns for order $m=3$ [11]

$\operatorname{PermEn}_{x}(m, I)$ has values in the range $0 \leq \operatorname{PermEn}_{x}(m, I) \leq \log m !, \operatorname{PermEn}_{x}(m, I)=0$ corresponds to the case when signal values are totally predictable, they are only ascending or descending. PermEn $n_{x}(m, I)=\log m$ ! corresponds to the case when signal contains all possible patterns with equal probability (the signal values are random numbers). To get rid of the PE dependence on the order, normalized $P E$ is introduced with values lying between 0 and 1 :

$$
\operatorname{PermEn}(m, I)=\frac{-\sum_{j=1}^{m !} p\left(\pi_{j}\right) \log p\left(\pi_{j}\right)}{\log m !} .
$$

\section{Experimental results and discussion}

In the Fig. 5 the results of fetal R-peaks detection procedure are presented. Obtaining a rhythmogram having the ECG with fetal constituents may be a challenging task due to the overlapping of fetal QRS complexes over the maternal ones. Since the maternal ECG signal is 315 times larger than fetal ECG special effort of distinguishing the QRS complexes should be made. To show this, we detected only maternal Rpeaks by standard technique (Fig. 6), and then removed them from the presumably fetal-only $R$ peaks signal. After obtaining the signal with significantly less peaks, which are believed to belong to the fetal heart beats only (Fig. 7). Despite the fact that there is the possibility of maternal and fetal heart beats overlapping, the study if this is common satiation should be done. In the following, the two peaks sequences are analyzed: raw one (Set 1) and another with maternal peaks subtracted (Set 2).

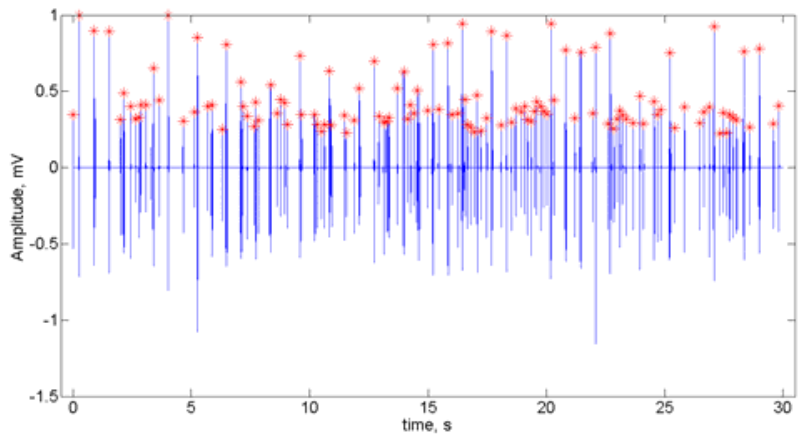

Fig. 5. 30-second processed maternal ECG signal with detected fetal R-peaks

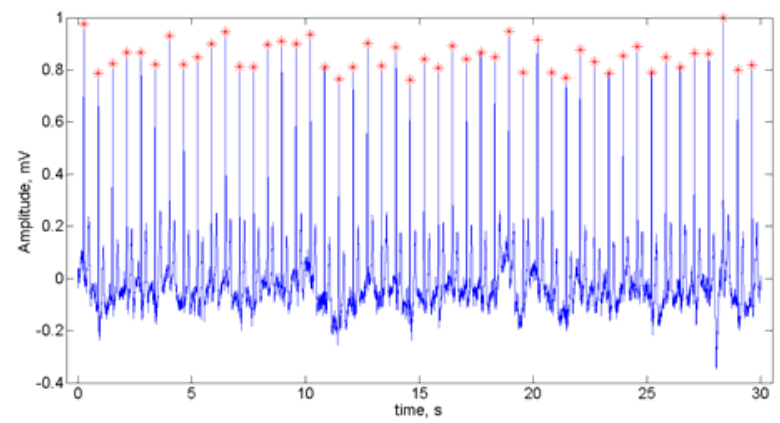

Fig. 6. 30-second raw maternal ECG with detected Rpeaks 


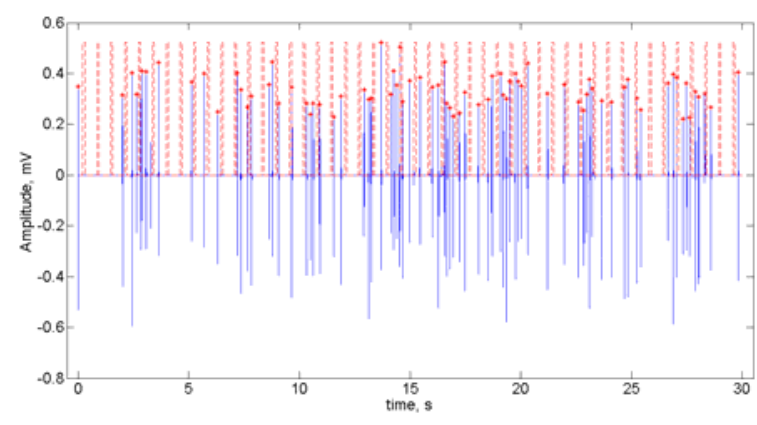

Fig. 7. 30-second processed presumably only-fetal ECG signal with detected fetal R-peaks and subtracted maternal ones, that are designated by dashed rectangles on corresponding places

After that two rhythmograms were obtained using data from Set 1 and 2 (Figs. 8-10 respectively).

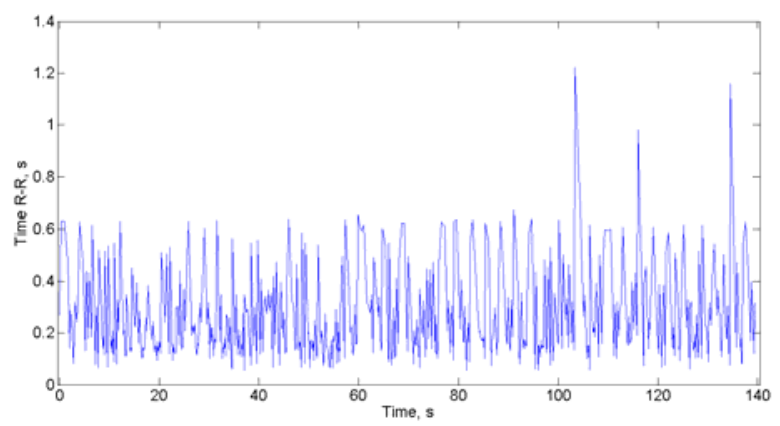

Fig. 8. Raw fetal rhythmogram (Set 1)

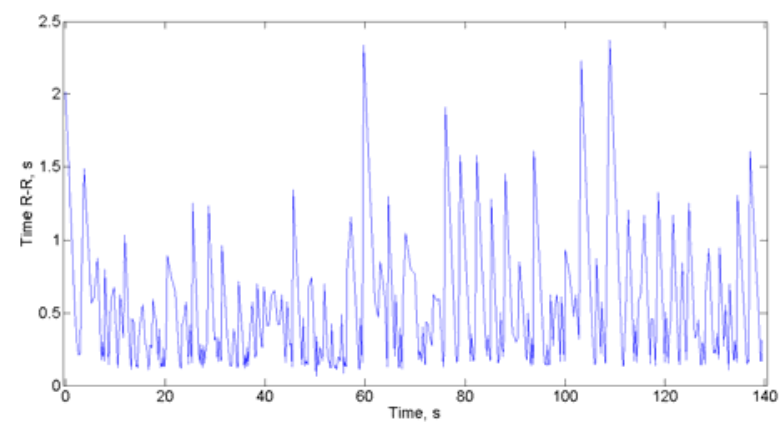

Fig. 9. Fetal rhythmogram with mother's heartbeats excluded (Set 2)

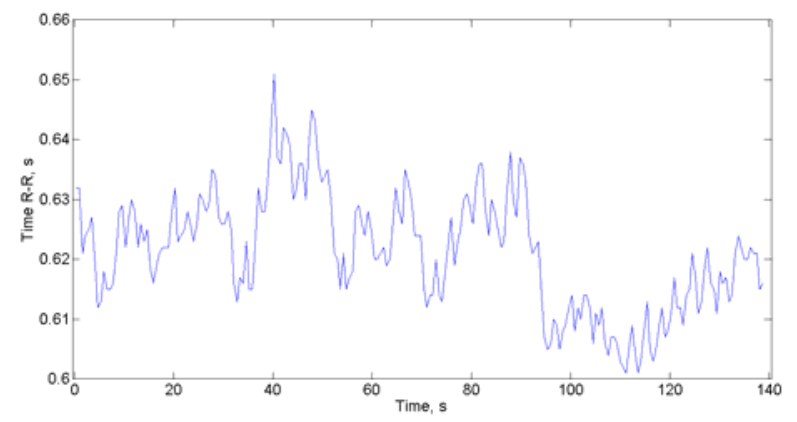

Fig. 10. Maternal rhythmogram
Then PE for the rhythmograms of Set 1 and Set 2 as explained above for orders from 3 to 5 was calculated. Two approaches were used to PE calculation: first, we calculated one PE value for whole rhythmogram, obtaining one value for each order. PE trend for each rhythmogram with different time windows ( $T W=50$ and $T W=200$ heartbeats) and then averaged PE values for all time windows were also calculated, resulting in one averaged PE value for each rhythmogram for each window duration. Typical PE trends for the case of order $\mathrm{m}=4$ are given in Fig. 11 (top - PE for Set 1, bottom - PE for Set 2). Results of PE calculations for two approaches are summarized in Table 1.
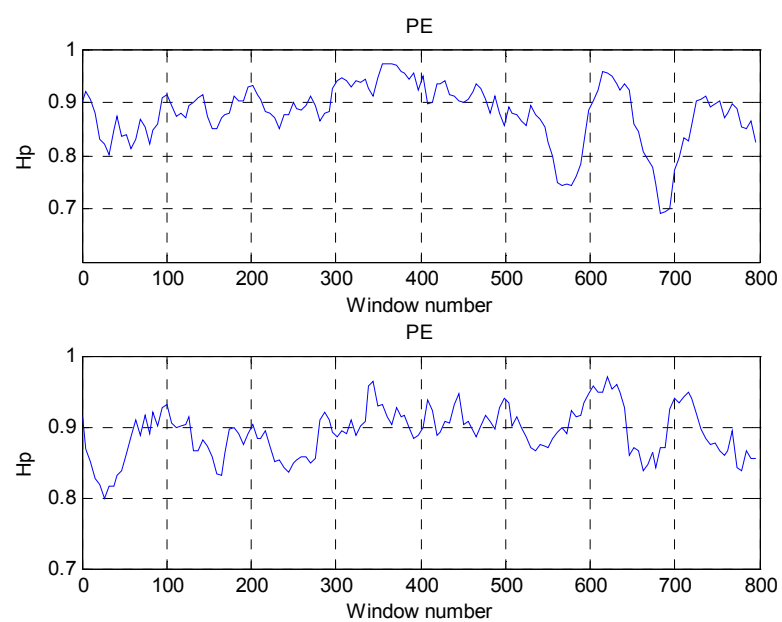

Fig. 11. PE trends for rhythmograms of Set 1 (top) and Set 2 (bottom), order $m=4$, time window is 50 heartbeats

It can be seen from Table 1 that fetal PE which is calculated for the whole signal is very close for the data from Set 1 and Set 2 . The largest difference equal to 0.02 for 5 th order, which is about 2 $\%$. Thus it's hard to distinguish between the two sets using PE value for whole signal. In the case when PE trend was analyzed, there are different average values for two sets for various PE orders: PE for Set 2, where maternal heartbeats were removed, is less in general than for Set 1 where maternal heartbeats are presumably present. The largest difference is for order 5 for both of time windows durations. The most prominent difference in for the large time window TW=200 heartbeats and for order $m=5$ : mean value for the Set 1 is 0.7 , and for Set 2 is 0.88 . Thus the assumption about the need to extract maternal heartbeats from initial $\mathrm{R}$-peaks sequence can be proven by the difference in PE values for Sets 1 and 2. 
Table 1.

\begin{tabular}{|c|c|c|l|l|}
\hline $\begin{array}{c}\text { Entropy } \\
\text { Order }\end{array}$ & $\begin{array}{c}\text { Fetal PE } \\
\text { (Set 1), } \\
\text { whole } \\
\text { signal }\end{array}$ & $\begin{array}{c}\text { Fetal PE } \\
\text { (Set 2), } \\
\text { whole } \\
\text { signal }\end{array}$ & $\begin{array}{c}\text { Fetal PE (Set 1), } \\
\text { averaging }\end{array}$ & \multicolumn{1}{c|}{$\begin{array}{c}\text { Fetal PE (Set 2), } \\
\text { averaging }\end{array}$} \\
\hline 3 & 0.98 & 0.98 & $\begin{array}{l}0.96 \pm 0.04(\mathrm{TW}=50) \\
0.98 \pm 0.01(\mathrm{TW}=200)\end{array}$ & $\begin{array}{l}0.97 \pm 0.02(\mathrm{TW}=50) \\
0.99 \pm 0.01(\mathrm{TW}=200)\end{array}$ \\
\hline 4 & 0.95 & 0.96 & $\begin{array}{l}0.88 \pm 0.06(\mathrm{TW}=50) \\
0.89 \pm 0.03(\mathrm{TW}=200)\end{array}$ & $\begin{array}{l}0.94 \pm 0.02(\mathrm{TW}=50) \\
0.96 \pm 0.01(\mathrm{TW}=200)\end{array}$ \\
\hline 5 & 0.90 & 0.92 & $\begin{array}{l}0.69 \pm 0.06(\mathrm{TW}=50) \\
0.70 \pm 0.04(\mathrm{TW}=200)\end{array}$ & $\begin{array}{l}0.85 \pm 0.04(\mathrm{TW}=50) \\
0.88 \pm 0.06(\mathrm{TW}=200)\end{array}$ \\
\hline
\end{tabular}

Thus it might be feasible to subtract maternal heartbeats from the $R$ peaks sequence when it is possible to detect peak from maternal ECG instead of fetal $R$ peak. The study of entropy characteristics of fetal heart activity obtained by unmixing of fECG from composite abdominal ECG can be useful for diagnostics.

\section{Conclusion}

Combining the fetal and maternal ECG separation techniques with entropy analysis, one can acquire new insights on fetus heart activity. The new technique of fECG extraction is used in this paper, based on filtration in wavelet domain and reconstruction of fECG using detalization coefficients. Permutation entropy analysis is applied to obtain PE values and trends for different time windows and steps. The assumption about the need to extract maternal heartbeats from initial rhythmogram is proven by the difference in PE values for the fetal rhythmogram and fetal rhythmogram obtained after extraction of maternal R-peaks.

\section{References}

1. Avilov, O. Permutation entropy of EEG signals for different sampling rate and time lag combinations / O. Avilov, A. Popov, O. Kanaikin // SPS-2013, 5-7 June 2013.: proceedings. - Warsaw, 2013. - ISBN 978-14673-6318-1.

2. Almagro, S. A New Mother Wavelet for Fetal Electrocardiography to Achieve Optimal Denoising and Compressing Results / S. Almagro, M. M. Elena, M. J. Bastiaans, J. M. Quero // Computers in Cardiology. 2006. - Vol. 33. - P. 157 - 160.

3. Bandt, C. Permutation entropy: A natural complexity measure for time series / C. Bandt, B. Pompe // Physical Review Letters. - 2002. - Vol. 88. - ISSN 1079-7114.

4. M. Cesarelli, M.Romano, P.Bifulco, "Comparison of short term variability indexes in cardiotocographic foetal monitoring," Computers in Biology and Medicine, vol. 39, 2009, pp. 106-118.

5. V. Chudáček et al., "Automatic evaluation of intrapartum fetal heart rate recordings: a comprehensive analysis of useful features," Physiological Measures, 2011, vol. 32, pp. 1347-1360.

6. Hoyer D. et al. "Fetal development assessed by heart rate patterns - Time scales of complex autonomic control," Computers in Biology and Medicine, vol. 42, 2012, pp. 335341.

7. Karvounis, E. C. Fetal Heart Rate Extraction from Composite Maternal ECG Using Complex Continuous Wavelet Transform/ E. C. Karvounis, C. Papaloukas, D. I. Fotiadis, L. K. Michalis// Computers in Cardiology. - 2004. - Vol. 31. - P. 737 740.

8. Pan, J.; Tompkins, W.J. "A Real-Time QRS Detection Algorithm," IEEE Transactions on Biomedical Engineering, vol. BME-32, issue 3, 1958, pp. 230-236.

9. S. Voskresenskyi, "Fetal state evaluation: Cardiatocography, Dopplerometry, Biophisical profile,” Minsk, “Knizhnyi Dom”2004, 304 p. (In Russian)

10. Vrins, F. Sensor Array and Electrode Selection for Non-invasive Fetal Electrocardiogram Extraction by Independent Component Analysis / F.Vrins, C. Jutten, M. Verleysen// Independent Component Analysis and Blind Signal Separation. Lecture Notes in Computer Science. - 2004. - Vol. 3195. - P. 1017 - 1024.

11. Xiaoli, Li. Estimating coupling direction between neuronal populations with permutation conditional mutual information / Xiaoli Li, GaoxiangOuyang // Neurolmage - 2010 Vol. 52 - P. 497-507.

Поступила в редакцию 23 октября 2013 г. 
УДК 621.391

О.О. Авілов, І.І. Боровський, К.О.Іванько, канд. техн. наук, М.А. Жуков,

А.О. Попов, канд. техн. наук, В.А. Фесечко, канд. техн. наук

Національний технічний університет України «Київський Політехнічний Інститут», вул. Політехнічна 16, 03056, Київ, Україна.

\section{Ентропія перестановок серцевого ритму плоду при вилученні ударів серця матері}

Розробка і застосування методів ідентифрікації фрізіологічних станів для матері та плоду, заснованих на неінвазивному моніторингу серцевої діяльності, має велике клінічне значення під час вагітності. У даній роботі досліджуються нові можливості застосування ентропії перестановок (ЕП) - одного з нелінійних методів часового аналізу серцевих скорочень плода. ЕП використовується для описання ритмограм плоду з метою отримання нових даних щодо характеристик серцевого ритму плода. Використовується нова методика виділення фетальної електрокардіограми (фЕКГ), заснована на фільтрації у вейвлет-просторі та реконструкції фьЕКГ з використанням коефріцієнтів деталізації.

Ентропія перестановок застосовується для отримання числових значень та часових залежностей ЕП для серцевого ритму у випадку необроблених ритмограм плоду та ритмограм, отриманих з виділеними ударами серия матері. Припущення про необхідність видаляти удари серия матері із початкової ритмограми підтверджується різницею у значеннях ЕП для двох випадків. Бібл. 11, рис. 11.

Ключові слова: ентропія перестановок, частота серцевих скорочень, варіабельність серцевого ритму (ВСР), електрокардіограма (ЕКГ), фьЕКГ, ЕКГ плоду, материнська ЕКГ, виявлення R-зубців.

УДК 621.391

А.А. Авилов, И.И. Боровский, М.А. Жуков, Е.О. Иванько, канд. техн. наук,

А.А. Попов, канд. техн. наук, В.А. Фесечко, канд. техн. наук

Национальный технический университет Украины «Киевский Политехнический Институт», ул. Политехническая 16, 03056, Киев, Украина.

\section{Энтропия перестановок сердечного ритма плода при изъятии ударов сердца матери}

Разработка и применение методов идентификации фризиологических состояний матери и плода, основанных на неинвазивном мониторинге сердечной деятельности, имеет большое клиническое значение при беременности. В данной работе исследуются новые возможности применения энтропии перестановок (ЭП) - одного из нелинейных методов временного анализа сердечных сокращений плода. ЭП используется для описания ритмограмм плода с целью получения новых данных о характеристиках сердечного ритма плода. Используется новая методика выделения фретальной электрокардиограммы (фЭКГ), основанная на фильтрации в вейвлетпространстве и реконструкции фрЭКГ с использованием коэффрициентов детализации.

Энтропия перестановок применяется для получения числовых значений и временных зависимостей ЭП для сердечного ритма в случае необработанных ритмограмм плода и ритмограмм, полученных с выделенными ударами сердца матери. Предположение о необходимости удалять удары сердца матери из начальной ритмограммы подтверждается разницей в значениях ЭП для двух случаев. Библ. 11, рис. 11.

Ключевые слова: энтропия перестановок, частота сердечных сокращений, вариабельность сердечного ритма, электрокардиограмма (ЭКГ), фђКГ, ЭКГ плода, ЭКГ матери, обнаружение $R-$ - зубцов. 


\section{Список использованных источников}

1. Avilov O., Popov A., Kanaikin O. (2013), "Permutation entropy of EEG signals for different sampling rate and time lag combinations". SPS-2013, 5-7 June. Warsaw. ISBN 978-1-4673-6318-1.

2. Almagro S., Elena M. M., Bastiaans M. J., Quero J. M. (2006), "A New Mother Wavelet for Fetal Electrocardiography to Achieve Optimal Denoising and Compressing Results". Computers in Cardiology, vol. 33, pp. 157-160.

3. Bandt C., Pompe B. (2002), "Permutation entropy: A natural complexity measure for time series". Physical Review Letters,, vol. 88. ISSN 1079-7114.

4. Cesarelli M., Romano M., Bifulco P. (2009), "Comparison of short term variability indexes in cardiotocographic foetal monitoring," Computers in Biology and Medicine, vol. 39, pp. 106-118.

5. Chudáček V. (2011), "Automatic evaluation of intrapartum fetal heart rate recordings: a comprehensive analysis of useful features," Physiological Measures,, vol. 32, pp. 1347-1360.

6. Hoyer D. et al. (2012), "Fetal development assessed by heart rate patterns - Time scales of complex autonomic control," Computers in Biology and Medicine, vol. 42, pp. 335-341.

7. Karvounis E. Papaloukas C., Fotiadis D. I., Michalis L. K. (2004), "Fetal Heart Rate Extraction from Composite Maternal ECG Using Complex Continuous Wavelet Transform". Computers in Cardiology, vol. 31, pp. 737-740.

8. Pan, J.; Tompkins, W.J. (1958), "A Real-Time QRS Detection Algorithm," IEEE Transactions on Biomedical Engineering, vol. BME-32, issue 3, pp. 230-236.

9. Voskresenskyi S. (2004), "Fetal state evaluation: Cardiatocography, Dopplerometry, Biophisical profile," Minsk, "Knizhnyi Dom”, 304 p. (In Russian)

10. Vrins F., Jutten C., Verleysen M. (2004), "Sensor Array and Electrode Selection for Non-invasive Fetal Electrocardiogram Extraction by Independent Component Analysis". Independent Component Analysis and Blind Signal Separation. Lecture Notes in Computer Science, vol. 3195, pp. 1017-1024.

11. Xiaoli Li, Gaoxiang Ouyang. (2010), "Estimating coupling direction between neuronal populations with permutation conditional mutual information". Neurolmage, vol. 52, pp. 497-507. 